\title{
Conservation conflicts involving mammals in Europe
}

Miguel Delibes-Mateos ${ }^{1,2,3}$

\begin{abstract}
${ }^{1} \mathrm{CIBIO} / \mathrm{InBIO}$, Universidade do Porto, Campus de Vairao 4485-661, Vairao Vila do Conde, Portugal. E-mail: mdelibesmateos@gmail. com.

${ }^{2}$ Instituto de Estudios Sociales Avanzados (IESA-CSIC). Campo Santo de los Mártires 7 14004, Córdoba, Spain.

${ }^{3}$ Intituto de Investigación en Recursos Cinegéticos (IREC; CSIC-UCLM-JCCM). Ronda de Toledo s/n 13071, Ciudad Real, Spain.
\end{abstract}

\begin{abstract}
Introduction: In recent times, conflicts involving wildlife have increased in importance and magnitude. Conservation conflicts occur when two or more parties with strongly held opinions clash over conservation objectives, and when one party is perceived to assert its interest at the expense of another. Conservation conflicts usually emerge from "wildlife impacts", defined as circumstances where people, consciously or unconsciously, negatively impact wildlife, or alternatively where wildlife negatively impacts the well-being or livelihoods of people or biodiversity. In Europe, the most frequent and intense conservation conflict associated with the management of mammals is likely that involving predators. For example, large carnivores depredate on livestock and game species, but at the same time these are flagship-species for European nature conservation. Therefore, conflicts about how these species should be managed emerge frequently. The management of overabundant ungulates that negatively impact natural vegetation as well as that of small mammals that damage crops also lead to frequent clashes between stakeholders in Europe. The global conservation status of most conflictive European mammals is rather good. However, some of their populations are threatened, at least partially by illegal killing and poaching. From this perspective, efforts are needed to mitigate conservation conflicts in these areas. In addition, promoting the investigation of conservation conflicts that incorporates multidisciplinary approaches is essential to increase the understanding of such conflicts and ultimately to mitigate them.
\end{abstract}

Key words: Crop damage, hunting, large carnivores, livestock loss, overabundant ungulates, poaching, predator control, small mammals, wildlife management

\section{Introduction}

Conflicts involving wildlife have existed since time immemorial. For example, several centuries ago European rabbits (Oryctolagus cuniculus) were transported from their native range in southern Europe to many places, because they are furry and edible animals. However, these small mammals devastated cereal crops, hence impacting negatively the interests of farmers (Thompson and King 1994), and causing tensions between stakeholders. Over recent times, however, with increasing pressure on ecosystem goods and services and increasing urgency for biodiversity conservation, these conflicts have likely become more important (Young et al. 2010). This seems to have captured the attention of the international scientific community, as the number of studies dealing with conflicts involving wildlife has exponentially increased during the last years (Figure 1). 
My main goal in this article is to explore conservation conflicts involving mammals in Europe. To do so, I will: 1) define conservation conflicts, since there is currently an important misunderstanding in the literature regarding this issue (Peterson et al. 2010); defining conservation conflicts is essential to better understand their significance in order to develop ways to manage them efficiently (Young et al. 2010); 2) describe the main types of conservation conflicts involving mammals in Europe; 3 ) review the impacts caused by wildlife on human well-being or biodiversity, which are ultimately responsible for most of the conflicts; 4) show the main stakeholders involved in conservation conflicts within Europe; 5) provide key examples of the main European mammal species involved in such conflicts; and 6) briefly discuss how conservation conflicts affect the conservation of mammals in the European context.

\section{Conservation conflicts: definition and types}

Conflict definitions generally converge around "expressed disagreements among people who see incompatible goals and potential interference in achieving these goals" (Pearce and Littlejohn 1997; Peterson et al. 2002; Pruitt and Kim 2004). In this sense, the term "human-wildlife conflict", which is commonly used to refer to conflicts involving wildlife species, is problematic because it suggests that animals are direct human antagonists (Graham et al. 2005; Peterson et al. 2010). In reality, conflicts tend to occur among humans ascribing different values to wildlife and thus how best to address its potential threats to human property, health, safety, etc. (Conover 2002).

In this context, conservation conflicts are defined as situations that occur when two or more parties with strongly held opinions clash over conservation objectives, and when one party is perceived to assert its interest at the expense of another (Redpath et al. 2013). Conservation conflicts emerge when either the positions of parties representing conservation interests are threatened by the positions of those holding other views and interests (e.g. farmers, hunters, etc) or when the objectives of conservation are imposed on others, such as when humans are excluded from protected areas or when species of conservation interest have an impact on

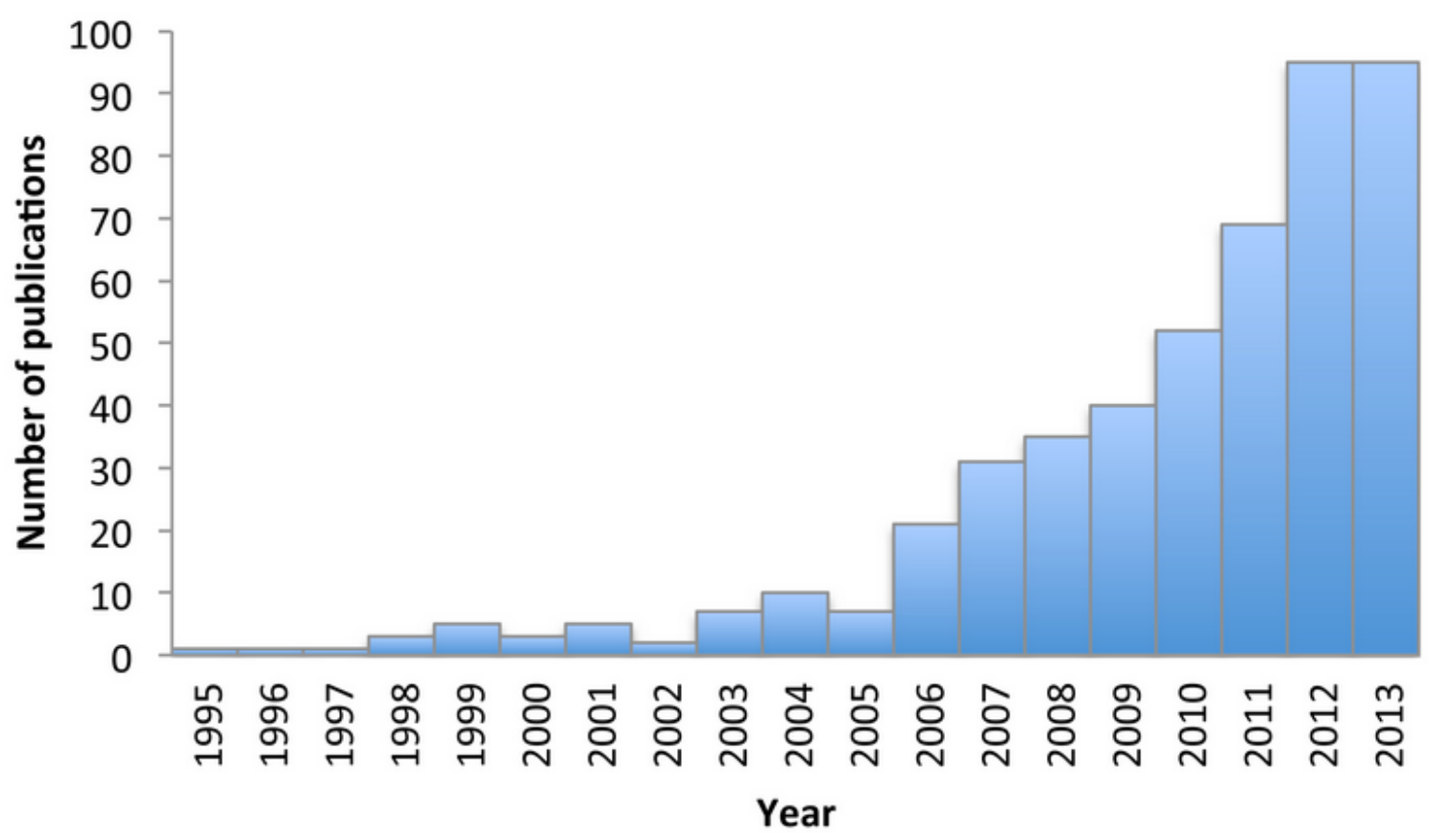

Figure 1. Trend in the number of publications containing the terms human-wildlife and conflict in the abstract, title or keywords, according to the Scopus search engine (www.scopus.com). 
humans (Redpath et al. 2013). This means that conservation conflicts always involve people with interests in biodiversity conservation (i. e. conservationists), excluding therefore conflicts only involving other stakeholders.

The example of reindeer (Rangifer tarandus) management in northern Europe illustrates well the differences between conservation conflicts and conflicts involving other stakeholders. On the one hand, reindeer husbandry is tightly connected to the indigenous Sámi people and depends on accessibility to natural pastures, which are menaced by the intensive management of the forestry industry; i. e. a conflict between Sámi people and forest owners exists (Pape and Löffler 2012; Saarikoski and Raitio 2013), but this is not a conservation conflict. On the other hand, reindeer overgrazing has been considered on some occasions as synonymous with habitat degradation or even an ecological disaster, causing tensions between conservationists and Sámi people (Pape and Löffler 2012); i. e. a conservation conflict.

Typically, conservationists come into conflict with other stakeholders regarding the management of wildlife. On the one hand, conservationists may aim to boost the numbers of a particular species because it is endangered, emblematic and/or plays major ecological roles, but this species negatively impacts the interests of other stakeholders (e.g. hunters, farmers, etc), who demand that the species' abundance be reduced (Figure 2a). This would be, for example, the case of the conflicts generated by the management of large carnivores in Europe. On the other hand, conservationists may aim to reduce the abundance of a particular species, because it detrimentally affects other species/habitats, but this reduction clashes with the interests of other stakeholders (e.g. hunters), who promote an increase in the species' numbers (Figure 2b). In Europe, a good example of this comes from the management of some overabundant ungulates.

\section{Wildlife impacts leading to conservation conflicts}

Conservation conflicts involving wildlife emerge from "wildlife impacts", defined as circumstances where people, consciously or unconsciously, negatively impact wildlife, or alternatively where wildlife negatively impacts the well-being or livelihoods of people (Young et al. 2005, 2007), or biodiversity. The impacts of human activities on wildlife are well known and include poaching, poisoning, hunting, habitat degradation, fragmentation and destruction. For example, in Europe, as in other places, some populations of large carnivores have been restricted and reduced because of habitat loss, poaching and poisoning (Liberg et al. 2012; Silva et al. 2013).

The impact of wildlife on the well-being or livelihoods of people or on biodiversity is usually known as wildlife damage, and it can refer to anything wildlife do that humans dislike (Conover 2002). The most frequent types of wildlife damage are shown in Table 1. Perhaps one of the most extensive types of wildlife damage across the world is the consumption of crops by wild species (e. g. Delibes-Mateos et al. 2011; Kroos et al. 2012; Haney and Conover 2013). Crop damage caused by mammals is frequent across Europe, including the central and southern regions (e. g. Barrio et al. 2010; Bleier et al. 2012; Ficetola et al. 2014). On most of these occasions, ungulates and small mammals are responsible for crop damage (see examples below). Interestingly, the intensification of agriculture that has occurred in some European regions has reduced the availability of natural food sources for wildlife, forcing them to feed on crops (Barrio et al. 2013), and increasing the possibility that conflicts between stakeholders emerge.

On some occasions, wildlife cause damage in gardens and other human properties that are not used for subsistence purposes (Table 1). For example, in Australia northern brown bandicoots (Isoodon macrourus), medium-sized terrestrial marsupials, dig holes in lawns and gardens in search of food (FitzGibbon and Jones 2006). In Europe, damage caused by wildlife in gardens and other human properties is not very common, and rarely leads to conservation conflicts. Examples include 
European moles (Talpa europaea) that form molehills in gardens and sports fields, and these are viewed as aesthetically unattractive, act as sites for weed invasions and cause soil degradation (Edwards et al. 1999), and herbivores that may also cause occasional damage in gardens through grazing, browsing or rooting.
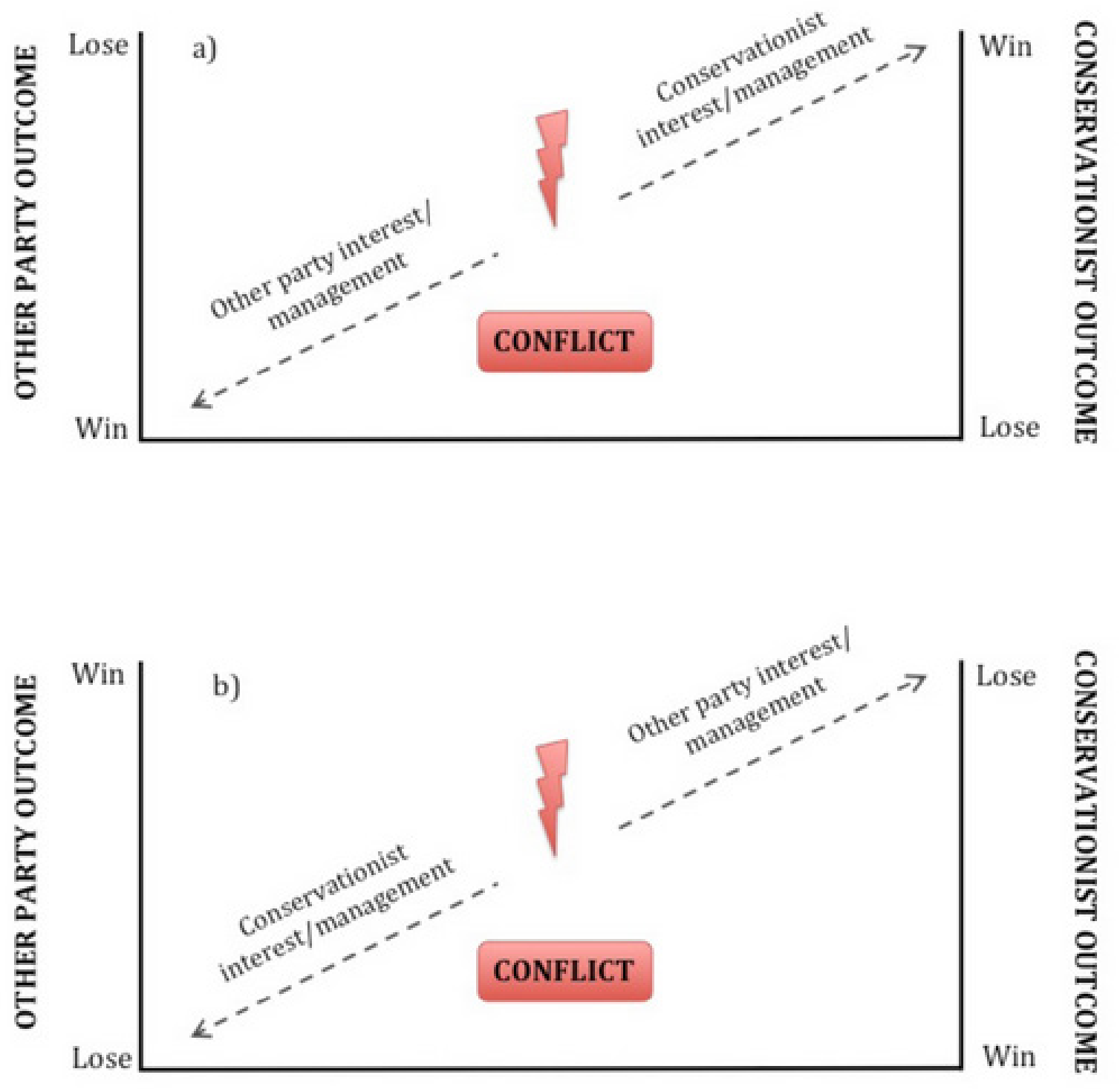

\section{SPECIES ABUNDANCE}

Figure 2. Two typical types of conservation conflicts involving mammals in Europe (inspired by Redpath et al. 2013). a) Conservationists aim to increase the numbers of a species of conservation concern (e. $g$. large predators), but this clashes with the interests of other stakeholders, who prefer reducing the species' abundance. b) The interest of conservationists is reducing the abundance of a species that negatively impacts biodiversity (e.g. overabundant ungulates), contrasting with the efforts made by other parties to increase the species' numbers. In both cases, conflicts emerge, because either conservationists or the other party are striving to win with little compromise shown towards other interests (see text for more details).

Wildlife can also negatively impact natural ecosystems (Coté et al. 2004). In this regard, damage caused by overabundant ungulates to plant diversity and vegetation structure, dynamics and composition constitutes a very good example that has been frequently recorded in diverse European regions (e. g. Fuller and Gill 2001; Perea et al. 2014). Given that the populations of ungulates have increased notably all over Europe (e.g. Acevedo et al. 2011), their damage to crops and natural 
ecosystems have become very common, leading to relatively frequent conservation conflicts.

Other typical examples of wildlife damage is predators' consumption of livestock, poultry, game species or fishes (Table 1), which occur almost all over the world (e. g. Amador-Alcalá et al. 2013; Li et al. 2013). Large carnivore depredation on livestock and big game species occurs in most European regions, particularly in eastern and northern areas (e. g. Odden et al. 2002, 2006; Kovarik et al. 2014). Over the last decades, populations of large carnivores have recovered in many European areas, either because of natural expansion or reintroduction programs (e. g. Linnell et al. 2009). This has brought a new source of ungulate mortality (i. e. depredation) in some places (e. g. Nowak et al. 2011), potentially creating new conflicts (see examples below). Also, small and medium-sized carnivores often depredate on small game species in different European areas (e. g. Díaz-Ruiz et al. 2013), and the frequent reaction of game managers is usually reducing the predators' numbers (e. $g$. DelibesMateos et al. 2013). Predator control either for hunting or conservation purposes is a common source of conflicts between stakeholders, and tensions can be common between conservationists about how these predators have to be managed. For example, some conservationists have requested reducing the numbers of pine martens (Martes martes) in the Cantabrian Mountains (northern Spain) as a measure to recover the populations of the endangered carpercaille (Tetrao urogallus), but others strongly oppose to this management as martens are legally protected. A particular case of wildlife damage caused by mammalian predators is that concerning the consumption of fishes by otters (e. $g$. Barbieri et al. 2012). In Europe, fish predation by Eurasian otters (Lutra lutra) has been recorded both in southern and central regions, where this constitutes a source of conservation conflicts (Freitas et al. 2007; Vacklavikova et al. 2011).

Table 1. Wildlife damage that may lead to conflicts between stakeholders (inspired by Peterson et al. 2010). In each particular case, the main damaging mammal species as well as the main stakeholders with opposite interests are shown. Types of wildlife damage are listed as a function of the frequency with which they lead to conservation conflicts in Europe (from the most common to the least).

\begin{tabular}{|c|c|c|c|}
\hline Wildlife damage & $\begin{array}{l}\text { Main damaging mammal } \\
\text { species }\end{array}$ & $\begin{array}{l}\text { Main stakeholders } \\
\text { promoting species } \\
\text { reduction }\end{array}$ & $\begin{array}{c}\text { Main stakeholders } \\
\text { promoting species } \\
\text { increase/conservation }\end{array}$ \\
\hline $\begin{array}{l}\text { Depredation on livestock and } \\
\text { poultry }\end{array}$ & Carnivores & Livestock producers & Conservationists \\
\hline Depredation on game species & Carnivores & Hunters & Conservationists \\
\hline Crop damage & Small mammals & Farmers & Conservationists \\
\hline Damage to natural vegetation & Ungulates & Conservationists & Hunters \\
\hline Depredation on fish species & Eurasian otter (Lutra lutra) & Fishermen & Conservationists \\
\hline $\begin{array}{l}\text { Kill people and disease } \\
\text { transmission to humans }\end{array}$ & $\begin{array}{c}\text { Large carnivores and } \\
\text { ungulates }\end{array}$ & Local people & Conservationists \\
\hline Damage to gardens/properties & $\begin{array}{l}\text { Ungulates and small } \\
\text { mammals }\end{array}$ & Local property owners & Conservationists \\
\hline $\begin{array}{l}\text { Damage to transportation } \\
\text { infrastructures and car accidents }\end{array}$ & $\begin{array}{l}\text { Ungulates and large } \\
\text { carnivores }\end{array}$ & Governments, Local people & Conservationists \\
\hline $\begin{array}{l}\text { Transmission of diseases to } \\
\text { livestock }\end{array}$ & Ungulates & Livestock producers & Hunters \\
\hline Crop damage & Ungulates & Farmers & Hunters \\
\hline Damage to forests & Ungulates & Forestry industry & Hunters \\
\hline
\end{tabular}

Many wildlife species can play a major role in the transmission of diseases to domestic animals (Table 1). For example, the existence of wildlife reservoirs complicates the control of bovine tuberculosis (bTB), an important re-emerging zoonotic disease that causes major economic losses and constrains international trade of animals and their products (Wedlock et al. 2002). In Europe, major problems with TB occur in areas with a high density of susceptible wild species hosts, such as the Eurasian badger (Meles meles) in Great Britain and Ireland, or ungulates in the Iberian Peninsula (Gortázar et al. 2012). 
This usually causes tensions between livestock producers and other stakeholders (e. g. hunters who aim to increase ungulate densities), although these conflicts rarely involve conservationists (Table 1).

During the last decades, the increase in transportation infrastructures, traffic volume and traffic speed together with the increase in the numbers of some wild life species have caused a substantial increase in wildlife-vehicle-accidents (Steiner et al. 2014). These not only result in high economic costs due to damage to vehicles and infrastructures, but also result in many injured and dead people every year (Table 1). In general, the most costly accidents caused by wildlife involve largebodied animals, such as ungulates and large predators. In Europe, collisions between vehicles and wildlife species are distributed from northern to southern regions (e. g. Mysterud 2004; ColinoRabanal et al. 2011, respectively). However, conservation conflicts rarely emerge from wildlifevehicle-accidents, except when the species responsible for such collisions are endangered or protected.

Wildlife can also frighten, or injure, kill humans and transmit infectious agents to them (i.e. damage to human safety; Table 1). Wildlife attacks to human are frequent in some regions across the world (Thirgood et al. 2005), but at present these only occur very occasionally in Europe (e. g. Swenson et al. 1999; Linnell et al. 2002). The transmission of infectious agents to Europeans is more frequent, but it is not usually associated with conservation conflicts (Table 1), as host wild species are usually abundant and unprotected.

\section{Stakeholders involved in conservation conflicts}

In Europe, the main stakeholders that come into conflict with conservationists as a consequence of wildlife impacts are livestock breeders, hunters and farmers (Table 1). Other sectors are only occasionally involved in conservation conflicts or at a local scale; for example, the aforementioned conflict involving otters that depredate fisheries (Table 1).

Livestock breeding is an important economic activity throughout Europe. Thus, in 2007 the total European livestock population amounted to 136 million livestock units, of which cattle represented $47.7 \%$, followed by pigs ( $27.6 \%$ ), poultry (13.8\%) and sheep (7.8\%; http://epp.eurostat.ec.europa. $\mathrm{eu})$. In many European regions, livestock populations share habitats with wildlife, which facilitates the potential for conflicts between livestock producers and conservationists. In fact, tensions between these stakeholders, for example, as consequence of livestock depredation by wildlife, are very common (Table 1 ).

Farming has a big influence on Europe's landscapes and ecosystems. Although farmers represent only $4.7 \%$ of the European Union's (EU's) working populations, they manage nearly half of the EU's land area (> 170 million hectares; http://epp.eurostat.ec.europa.eu). The loss of traditional farming practices to intensive agriculture in some European regions has led to biodiversity impoverishment (e. g. Donald et al. 2001). However, a large number of highly valuated wildlife species and semi-natural habitats types in Europe are still dependant on continuing low-intensity agricultural practices (Bignal and McCracken 2000). In this context, conflicts can arise between conservationists and farmers about how wildlife species should be managed. For example, farmers may demand reducing the numbers of wildlife species that damage crops, whereas conservationists may promote boosting their populations (Table 1).

In Europe, hunting involves millions of people as participants and beneficiaries. It is undertaken on millions of hectares of land, and it generates millions of euros in income. Hunting is practiced across most of the European territory, and it is mostly focused on wild ungulates (e.g. moose Alces alces, wild reindeer, roe deer Capreolus capreolus, red deer Cervus elaphus, fallow deer Dama dama, wild boar Sus scrofa), carnivores (e.g. brown bear Ursus arctros, wolf Canis lupus, Eurasian lynx 
Lynx lynx, red fox Vulpes vulpes), lagomorphs (European rabbit Oryctolagus cuniculus; European brown hare Lepus europaeus, Iberian hare L. granatensis, mountain hare L. timidus), and game birds (e. $g$. capercaillie Tetrao urogallus, black grouse T. tetrix, willow grouse Lagopus lagopus, Rock ptarmigan $L$. muta, red-legged partridge Alectoris rufa, grey partridge Perdix perdix, pheasant Phaisanus colchicus, woodcock Scolopax rusticola, various waders, pigeons, ducks and geese). Hunting involves the killing of animals and this usually leads to tensions between different sectors of society. In particular, hunters frequently come into conflict with conservationists when, for example, species of conservation concern, such as large carnivores, are harvested or killed illegally (Table 1). These tensions also emerge when the hunt of some species is locally banned, owing to the claims of conservationists (Delibes-Mateos et al. 2014).

\section{Wildlife species involved in conservation conflicts}

In this section, I will provide some key examples of conservation conflicts involving mammals in Europe. Nevertheless, this does not pretend to be an exhaustive review that encompasses all the conflicts nor of all the specific issues within each particular example. The most noticeable conservation conflicts involving European mammals are perhaps those that have to do with large carnivores. The management of Europe's large carnivores is controversial and is increasingly a cause of debate. On the one hand, these species are flagship-species for European nature conservation. On the other hand, they can negatively impact livestock or other human interests (Table 1). In this regard, the conflict between livestock breeders and conservationists about the management of wolf populations is likely one of the best examples. It is estimated that there are a total of some 10,000 wolves spread across Europe, with the largest populations in the eastern regions (Carpathian and Dinaric-Balkan populations) and in northwestern Iberia (Silva et al. 2013). One of the biggest threats faced by Europe's wolves is illegal killing as a result of human antipathy of wolf presence. In Sweden, for example, illegal killing accounted for approximately half of the total mortality of wolves, and more than two-thirds of the total illegal killing remained undetected by conventional methods (Liberg et al. 2012). Both illegal killing and support for illegal killing and hunting violators are based on anger and fear for children and domestic animals, as well as frustration toward the authorities and the lack of proper management actions (Pohja-Mykrä and Kurki 2014). Illegal killing undermines the strong conservation efforts directed at European wolves (Silva et al. 2013), and therefore causes frequent tensions between stakeholders (Gangaas et al. 2013).

In addition, wolves are a game species in several European countries, and conflicts between hunters and conservationists regarding the management of wolves are common. For example, the Spanish government has recently requested the EU to approve wolf hunting south of the Douro River, something that is currently prohibited. The Spanish conservation community has immediately reacted and in only a few days collected through social networks the support of $>100,000$ people who oppose this petition. Finally, wolf populations have expanded widely across Europe, and wolves have reappeared in areas where they became extinct long ago (Silva et al. 2013), increasing the possibility of conflicts not only because people are no longer accustomed to living alongside wolves, but also because the wolves' attacks on livestock may have increased in some areas. In Slovenia, for example, the number of small livestock (sheep and goats) killed by wolves increased from 218 in 2005 to 1931 in 2011 (van Liere et al. 2013).

The brown bear is one of the most emblematic large carnivores in Europe, where its number is estimated to have risen to 17,000 individuals, distributed across 10 populations (Silva et al. 2013). The Carpathian population in Eastern Europe is the largest, with more than 7,000 individuals, and the Alpine, Pyrenean and central Apennine populations are the smallest, with a few dozen individuals each. The bear is omnivorous and its diet consists of mostly nuts, fruits and many types of vegetables, 
as well as meat. Bears can damage crops (e. g. fruit trees) and depredate livestock (e. g. Meryens and Promberger 2000; Knarrum et al. 2006), causing certain animosity towards them in some areas (Rigg et al. 2011). This low acceptance of bear presence can lead to illegal killing, which is one of the main threats for European bear populations (e. g. Kaczensky et al. 2011), in addition to habitat loss and fragmentation. Nevertheless, sometimes bears are non-target victims of illegal trapping or poisoning that are directed to the killing of other species like wolves. In addition, disturbances caused by hunting and other recreational activities (hiking, wildlife watching, etc.) may also pose a risk for bear conservation in some European populations (Ordiz et al. 2012), hence causing conflicts between conservationists and other stakeholders.

The Eurasian lynx is distributed in northern, eastern and central Europe. It has been reintroduced to several of these areas (Linnell et al. 2009), particularly in central Europe, where it became extinct in the past. The latest estimate for the total number of lynx in Europe is 9,000 (Silva et al. 2013). It mainly occurs in forested areas and usually at low densities. This means that on many occasions people rarely see or interact with lynx. For example, in the Republic of Macedonia the level of interaction with this species is very low, and the lynx does not appear to be a species associated with conflicts (Lescureux et al. 2011). However, lynx frequently prey on game ungulates, such as roe deer, and livestock (e. g. Odden et al. 2002; Gervasi et al. 2014), causing a low acceptance of their presence in some areas, which results in persecution and illegal killing (Andrén et al. 2006). This causes conflicts between conservationists and hunters and livestock breeders, particularly in areas where lynx populations are recovering and expanding (e. g. Liukkonen et al. 2009; Breitenmoser et al. 2010). In addition, the legal killing of Eurasian lynx as a game species is often controversial, as conservationists feel that too many are being killed, and hunters and sheep farmers have the opposite feeling (Linnell et al. 2010).

The Iberian lynx (Lynx pardinus) is likely the most endangered felid in the world. Currently, less than 350 lynx persist in the Iberian Peninsula. During the last decades, huge conservation efforts have been conducted to recover Iberian lynx populations, and large sums of money have been invested to achieve this goal (Simón et al. 2012). The lberian lynx diet is almost exclusively based on European rabbits (Ferreira and Delibes-Mateos 2010), a very important game species in the lynx distribution area. Most Iberian lynx occur in private areas managed for hunting (Simón et al. 2012), and poaching is the main cause of lynx mortality in Sierra Morena (López et al. 2014), the largest lynx population. This causes important tensions between hunters and conservationists. In addition, conflicts with livestock breeders may also emerge as a consequence of occasional lynx depredation on lambs (Garrote et al. 2013). Furthermore, some sectors of society demand the development of new infrastructures (e.g. motorways in lynx distribution areas), coming into conflict with conservationists, as road-killing is one of the main causes of mortality of Iberian lynx (López et al. 2014).

Another conflict that takes place in southern Europe is that concerning the management of European rabbits. Over the past decades, European rabbit populations have declined sharply on the Iberian Peninsula (Delibes-Mateos et al. 2009), their native range. The recovery of rabbit populations is one of the biggest challenges for lberian conservationists, as rabbits play major ecological roles in Iberian Mediterranean ecosystems (reviewed in Delibes-Mateos et al. 2008), including as mentioned serving as prey for endangered predators like the Iberian lynx. On the other hand, the rabbit is also a very important game species in the Iberian Peninsula. In Spain, for example, more than 4 million rabbits are killed annually by hunters. Although hunters employ a diverse array of game management measures to allow rabbit numbers to increase, poorly managed and excessive hunting pressure has reduced their numbers in some areas, leading to clashes with conservationists (Delibes-Mateos et al. 2011, 2014). In addition, farmers promote rabbit control and sometimes eradicate them in areas where valuable crops are damaged (Ríos- 
Saldaña et al. 2013). Farmers' interests are therefore strongly opposed to those of conservationists and hunters, causing frequent conflicts (Delibes-Mateos et al. 2011, 2014).

Other European small mammals are also often involved in conservation conflicts. In some European countries, for example, anticoagulant rodenticides (i. e. bromadiolone) are sometimes applied intensively to control rodents that cause crop damage, such as common voles (Microtus arvalis) and water voles (Arvicola terrestris) in Spain and France, respectively (Olea et al. 2009; Coeurdassier et al. 2014). Anticoagulant rodenticides invariably cause secondary poisoning of non-target species, and bromadiolone particularly is known to affect predators and scavengers (Berny 2007). In France, for example, some raptors of conservation concern like red kites (Milvus milvus) and common buzzards (Buteo buteo) were poisoned by bromadiolone after a recent vole control campaign (Coeurdassier et al. 2014). Similarly, in Spain other protected bird species like the great bustard (Otis tarda) were affected by rodenticide treatments (Olea et al. 2009). The high level of poisoning of wildlife that follows such treatments over large areas is something that concerns conservationists and leads to frequent tensions between these and farmers (Ferreira and Delibes-Mateos 2012).

Land-use change and game management have favoured an increasing population of wild ungulates in many regions of Europe (Acevedo et al. 2011). Temperate European communities may have been currently supporting the highest densities of ungulates ever recorded. Overabundant ungulates usually cause detrimental effects to natural ecosystems. For example, high red deer densities (> 30 individuals $/ \mathrm{km}^{2}$ ) are causing biotic homogenization of plant communities in Mediterranean scrublands within the Iberian Peninsula and are forcing vegetation to return to earlier successional stages (Perea et al. 2014). Similar impacts have been reported for several ungulate species in northern Europe (e.g. Austin et al. 2013), and increasingly lead to conflicts between conservationists and hunters (Smart et al. 2008; MacMillan and Phillip 2010). Thus, while conservation groups frequently request shooting more ungulates (Putman et al. 2005), hunters are usually less supportive (MacMillan 2004). Nevertheless, conflicts regarding the management of overabundant ungulates seem to be still more acute when these negatively impact the interests of farmers or the forestry industry (e. $g$. Ezebilo et al. 2012).

\section{Conclusion}

1) Nearly all mammal species involved in conservation conflicts in Europe are not threatened globally according to the International Union for Conservation of Nature (IUCN 2014). The main exception is the critically endangered Iberian lynx. From this perspective, mitigating conflicts associated with the Iberian lynx management is a big challenge for conservation in Europe. Other mammal species frequently associated with conservation conflicts are mostly classified as "Least Concern", excepting European rabbit and Eurasian otter, which are listed as "Near Threatened". Recovering the declining populations of the European rabbit in the Iberian Peninsula should be still a major concern for European conservationists (Delibes-Mateos et al. 2014).

2) Although the global conservation status of most conflictive European mammals is rather good, some of their populations are threatened. For example, the European hamster (Cricetus cricetus), which is labelled as Least Concern in the IUCN red list (IUCN 2014), is currently highly threatened in Alsace (France). The main causes of hamster's decline are its persecution by farmers as agricultural pest several decades ago, and changes in agriculture and fragmentation caused by the construction of new infrastructures in the second half of the $20^{\text {th }}$ century. Conservation conflicts in these places are usually intense (e. g. Amores 2011), as conflicts tend to be greatest where the conservation of biodiversity and/or the livelihood of the other stakeholders are perceived to be most threatened (Marshall et al. 2007). Therefore, important efforts are needed to mitigate conservation conflicts in these areas. 
3) Conflicts involving European mammals may also affect other non-target species and ecosystem processes, thus impacting biodiversity. On the one hand, the intensive management aimed at reducing the numbers of some mammal species can kill non-target species, including some of conservation concern (Coeurdassier et al. 2014). On the other hand, the reduction in numbers of some mammal species of conservation concern as a consequence of other stakeholders' management may cause important cascading effects on other species and ecosystem processes (Delibes-Mateos et al. 2011).

4) Conflicts between people regarding how wildlife should be managed are not frequently addressed in scientific publications (Peterson et al. 2010). In addition, although understanding conservation conflicts requires integrating knowledge generated by many disciplines, including natural sciences, social sciences, and humanities (Redpath et al. 2013), this rarely occurs (Dickman 2010). From this perspective, promoting the investigation of conservation conflicts that incorporates multidisciplinary approaches is essential for the conservation of mammal species in Europe.

\title{
Acknowledgements
}

M. Delibes-Mateos has received funding from Consejería de Economía, Inovación, Ciencia y Empleo of Junta de Andalucía, and the European Union's Seventh Framework Programme for research, technological development and demonstration under grant agreement 267226. M. Delibes and two anonymous reviewers provided helpful comments on a previous draft of this manuscript. I thank Dr. W. Lidicker for his editorial assistance.

\section{Resumen}

\begin{abstract}
Los conflictos asociados a la gestión de la fauna se han incrementado en tiempos recientes. Los conflictos de conservación ocurren cuando dos o más partes con opiniones fuertemente enfrentadas chocan sobre objetivos de conservación, y cuando una parte mantiene firme sus intereses en detrimento de los de otra. Normalmente los conflictos de conservación surgen de los impactos sobre o de la fauna, definidos como circunstancias donde la gente, consciente o inconscientemente, impacta negativamente en la fauna, o cuando ésta causa efectos negativos en el bienestar o sustento de las personas o en la biodiversidad. En Europa los conflictos de conservación más frecuentes son probablemente aquellos relacionados con la gestión de los depredadores. Por ejemplo, los grandes carnívoros depredan sobre el ganado o las especies de caza, pero al mismo tiempo son especies bandera para la conservación. Por lo tanto, los conflictos sobre cómo se deberían de gestionar estas especies son habituales. La gestión de los ungulados que impactan negativamente en la vegetación natural así como la de los pequeños mamíferos que causan daños a los cultivos también provoca frecuentes enfrentamientos en Europa. El estado global de conservación de los mamíferos europeos conflictivos es bastante bueno. Sin embargo, algunas de sus poblaciones están amenazadas, al menos en parte por la caza ilegal y el furtivismo. Por lo tanto, es necesario realizar esfuerzos importantes para mitigar estos conflictos en estas áreas. Además, se debería de promover la investigación multidisciplinar de los conflictos de conservación para conocerlos mejor y en última instancia para mitigarlos.
\end{abstract}

Palabras clave: Caza, control de depredadores, daños a cultivos, daños al ganado, furtivismo, gestión de fauna, grandes carnívoros, pequeños mamíferos, sobreabundancia de ungulados

\section{Literarure cited}

Acevedo, P., M. A. Farfán, A. L. Márquez, M. Delibes-Mateos, R. Real, and J. M. Vargas. 2011. Past, present and future of wild ungulates in relation to changes in land use. Landscape Ecology 26:19-31.

Amador-Alcalá, S., E. J. Naranjo, and G. Jiménez-Ferrer. 2013. Wildlife predation on livestock and poultry: implications for predator conservation in the rainforest of south-east Mexico. Oryx 47:243-250.

Amores, J. A. B. 2011. The conflict caused by the introduction of bears in the Pyrenees. Different interpretations of the natural and national contracts. Revista Internacional de Sociología 69:439-460. 
Andrén, H., J. D. C. Linnell, O. Liberg, R. Andersen, A. Danell, J. Karlsson, J. Odden, P. F. Moa, P. Ahlpvist, T. Kvam, R. Franzén, and P. Segerström. 2006. Survival rates and causes of mortality in Eurasian lynx (Lynx lynx) in multi-use landscapes. Biological Conservation 131:23-32.

Austin, Z., D. G. Raffaelli, And P. C. L. White. 2013. Interactions between ecological and social drivers in determining and managing biodiversity impacts of deer. Biological Conservation 158:214-222.

Barbieri, F., R. Machado, C. A. Zappes, and L. R. D. Oliveira. 2012. Interactions between the Neotropical otter (Lontra longicaudis) and gillnet fishery in the southern Brazilian coast. Ocean and Coastal Management 63:16-23.

Barrio, I. C., C. G. Bueno, and F. S. Tortosa. 2010. Alternative food and rabbit damage in vineyards of southern Spain. Agriculture, Ecosystems and Environment 138:51-54.

Barrio, I. C., C. G. Bueno, R. Villafuerte, and F. S. Tortosa. 2013. Rabbits, weeds and crops: does agricultural intensification promote wildlife conflicts in semiarid agro-ecosystems? Journal of Arid Environments 90:1-4.

Berny, P. 2007. Pesticides and the intoxication of wild animals. Journal of Veterinary Pharmacology and Therapeutics 30:93-100.

Bleier, N., R. Lehoczkı, D. Újváry, L. Szemethy, And S. Csányı. 2012. Relationship between wild ungulates density and crop damage in Hungary. Acta Theriologica 57:351-359.

Bignal, E. M., AND D. I. McCRACKen. 2000. The nature conservation value of European traditional farming systems. Environmental Reviews 8:149-171.

Breitenmoser, U., A. Ryser, A. Molinari-Jobin, F. Zimmerman, H. Haller, P. Molinari, and C. Breitenmoser-Wursten. 2010. The changing impact of predation as a source of conflict between hunters and reintroduced lynx in Switzerland. Pp. 493-506 in Biology and conservation of wild felids (Macdonland, D. W., and A. J. Loverige, eds.). Oxford University Press. London, United Kingdom.

Coeurdassier, M., R. Riols, A. Decors, A. Mionnet, F. David, T. Quintaine, D. Truchelet, R. Scheifler, and P. GiRADoux. 2014. Unintentional wildlife poisoning and proposals for sustainable management of rodents. Conservation Biology 28:315-321.

Colino-Rabanal, V. J., M. Lizana, and S. J. Peris. 2011. Factors influencing wolf Canis lupus roadkills in Northwest Spain. European Journal of Wildlife Research 57:399-409.

Conover, M. R. 2002. Resolving human-wildlife conflicts: the science of wildlife damage management. Lewis Publishers. Boca Raton, Florida.

Coté, S. D., T. P. Rooney, J. P. Tremblay, C. Dussalt, and D. M. Waller. 2004. Ecological impacts of deer overabundance. Annual Review of Ecology, Evolution and Systematics 35:113-147.

Delibes-Mateos, M., M. Delibes, P. Ferreras, and R. Villafuerte. 2008. The key role of European rabits in the conservation of the western Mediterranean basin hotspot. Conservation Biology 22:1106-1117.

Delibes-Mateos, M., P. Ferreras, and R. Villafuerte. 2009. European rabbit population trends and associated factors: a review of the situation in the Iberian Peninsula. Mammal Review 39:124-140.

Delibes-Mateos, M., A. T. Smith, C. Slobodchikoff, and J. E. Swenson. 2011. The paradox of keystone species persecuted as pests: a call for the conservation of abundant small mammals in their native range. Biological Conservation 144:1335-1346.

Delibes-Mateos, M. S. Fernández-Díaz, P. Ferreras, J. Viñuela, and B. Arroyo. 2013. The role of economic and social factors driving predator control in small game estates in central Spain. Ecology and Society 38:18.

Delibes-Mateos, M., C. Ferreira, C. Rouco, R. Villafuerte, and I. C. Barrio. 2014. Conservationists, hunters and farmers: the European rabbit Oryctolagus cuniculus management conflict in the Iberian Peninsula. Mammal Review 44:190-203.

Díaz-Ruiz, F., M. Delibes-Mateos, J. L. García-Moreno, J. M. López-Martin, C. Ferreira, and P. Ferreras. 2013. Biogeographical patterns in the diet of an opportunistic predator: The red fox Vulpes vulpes in the Iberian Peninsula. Mammal Review 43:59-70. 
Dıckman, A. J. 2010. Complexities of conflict: the importance of considering social factors for effectively resolving human-wildlife conflict. Animal Conservation 13:458-466.

Donald, P. F., R. E. Green, and M. F. Heath. 2001. Agricultural intensification and the collapse of Europe's farmland bird populations. Proceedings of the Royal Society B: Biological Sciences 268:25-29.

Edwards, G. R., M. J. Crawley, and M. S. Heard. 1999. Factors influencing molehill distribution in grassland: implications for controlling the damage caused by molehills. Journal of Applied Ecology 36:434442.

Ezebilo, E. E., C. Sandström, and G. Ericsson. 2012. Browsing damage by moose in Swedish forests: assessments by hunters and foresters. Scandinavian Journal of Forest Research 27:659-668.

Ferreira, C., And M. Delibes-Mateos. 2010. Wild rabbit management in the Iberian Peninsula: state of the art and future perspectives for Iberian lynx conservation. Wildlife Biology in Practice 6:48-66.

Ferreira, C., and M. Delibes-Mateos. 2012. Conflictive management of small mammals considered as pests: a long way to evidence-based policy making. Current Zoology 58:353-357.

Ficetola, G. F., A. Bonardi, P. Mairota, V. Leronni, and E. Padoa-Schioppa. 2014. Predicting wild boar damages to croplands in a mosaic of agricultural and natural areas. Current Zoology 60:170-179.

FitzGibBon, S. I., AND D. N. Jones. 2006. A community-based wildlife survey: the knowledge and attitudes of residents of suburban Brisbane, with a focus on bandicoots. Wildlife Research 33:233-241.

Freitas, D., J. Gomes, T. Sales Luis, L. Madruga, C. Marques, G. Baptista, L. M. Rosalino, P. Antunes, R. Santos, And M. Santos-Rel. 2007. Otters and fish farms in the Sado estuary: ecological and socio-economic basis of a conflict. Hydrobiologia 587:51-62.

Fuller, R. J., AND R. M. A. Gill. 2001. Ecological impacts of increasing numbers of deer in British woodlands. Forestry 74:193-199.

Gangaas, K. E., B. P. Kaltenborn, and H. P. Andreassen. 2013. Geo-spatial aspects of acceptance of illegal hunting of large carnivores in Scandinavia. PLOS ONE 8: e68849.

Garrote, G., G. López, J. M. Gil-Sánchez, E. Rojas, M. Ruiz, J. M. Bueno, S. de Lillo, A. J. Rodríguez-Siles, J. M. Martín, J. Pérez, M. García-Tardío, G. Valenzuela, and M. A. Simón. 2013. Human-felid conflict as a further handicap to the conservation of the critically endangered Iberian lynx. European Journal of Wildlife Research 59:287-290.

Gervasi, V., N. B. Nielsen, J. Odden, Y. Bouyer, And J. D. C. Linnell. 2014. The spatio-temporal distribution of wild and domestic ungulates modulates lynx kill rates in a multi-use landscape. Journal of Zoology 292:175-183.

Gortázar, C., R. J. Delahay, R. A. Mcdonald, M. Boadella, G. J. Willson, D. Gavier-Widen, and P. Acevedo. 2012. The status of tuberculosis in European wild mammals. Mammal Review 42:193-206.

Graham, K., A. P. Beckerman, ANd S. ThiRgood. 2005. Human-predator-prey conflicts: ecological correlates, prey loses and patterns of management. Biological Conservation 122:159-171.

Haney, M. J., AND M. R. Conover. 2013. Ungulate damage to safflower in Utah. Journal of Wildlife Management 77:282-289.

IUCN. 2014. The IUCN Red List of Threatened Species. Version 2014.2. http://www.iucnredlist.org (Downloaded on September 2014).

Kaczensky, P., J. Jerina, And M. Jonozovic. 2011. Illegal killings may hamper brown bear recovery in the Eastern Alps. Ursus 22:37-46.

Knarrum, V., O. J. Sorense, T. Eggen, T. Kvam, O. Opseth, K. Overskaug, and A. Eidsmo. 2006. Brown bear predation on domestic sheep in central Norway. Ursus 17:67-74.

Kovarik, P., M. Kutal, ANd I. Machar. 2014. Sheep and wolves: is the occurrence of large predators a limiting factor for sheep grazing in the Czech Carpathians? Journal for Natural Conservation 22:479-486.

Kroos, S. M., J. M. Tylianakis, and X. J. Nelson. 2012. Effects of introducing threatened falcons into vineyards on abundance of Passeriformes and bird damages to grapes. Conservation Biology 
26:142-149.

Lescureux, N., J. D. C. Linnell, S. Mustafa, D. Melovski, A. Stojanov, G. Ivanov, V. Avukatov, M. Von Arx, and U. Breitenmoser. 2011. Fear of the unknown: Local knowledge and perceptions of the Eurasian lynx Lynx lynx in western Macedonia. Oryx 45:600-607.

Lı, X., P. Buzzard, Y. Chen, And X. Jiang. 2013. Patterns of livestock predation by carnivores: Human-wildlife conflict in Northwest Yunnan, China. Environmental Management 52:1334-1340.

Liberg, O., G. Chapron, P. Wabakken, H. C. Pedersen, N. Thompson Hobbs, and H. Sand. 2012. Shoot, shovel and shut up: cryptic poaching slows restoration of a large carnivore in Europe. Proceedings of the Royal Society B: Biological Sciences 279:910-915.

Linnell, J. D., R. Andersen, Z. Andersone, L. Balclauskas, J. C. Blanco, S. Brainerd, U. Breitenmoser, I. Kojola, O. Liberg, J. Loe, H. Okarma, H. C. Pedersen, C. Promberger, H. Sand, E. J. Solberg, H. Valdmann, and P. WABAKKen. 2002. The fear of wolves: a review of wolf attacks on humans. NINA Oppdragsmelding 731:1-65.

Linnell, J. D. C, U. Breitenmoser, C. Breitenmoser-Würsten, J. Odden, and M. Von Arx. 2009. Recovery of Eurasian lynx in Europe: what part has reintroduction played? Pp. 72-91 in Reintroduction of toporder predators? (Hayward M. W., and M. Somers, eds.). Blackwell Publishing Ltd. London, United Kingdom.

Linnell, J. D. C., H. Broseth, J. Odden, and E. B. Nilsen. 2010. Sustainable harvesting a large carnivore? Development of Eurasian lynx populations in Norway during 160 years of shifting policy. Environmental Management 45:1142-1154.

LiUkKonen, T., S. Mykrä, J. Bisı, And S. KURKı. 2009. Conflicts and compromises in Lynx Lynx lynx conservation and management in Finland. Wildlife Biology 15:165-174.

López, G., M. López-Parra, G. Garrote, L. Fernández, T. Rey-Wamba, R. Arenas-Rojas, M. García-Tardío, G. Ruiz, T. Zorrilla, M. Moral, AND M. A. Simón. 2014. Evaluating mortality rates and casualties in a critically endangered felid across its whole distribution range. European Journal of Wildlife Research 60:359366.

MacMillan, D. G. 2004. Tradeable hunting obligations - A new approach to regulating red deer numbers in the Scottish Highlands? Journal of Environmental Management 71:261-270.

MacMillan, D. G., ANd S. Phillip. 2010. Can economic incentives resolve conservation conflict: the case of wild deer management and habitat conservation in the Scottish Highlands. Human Ecology 38:485493.

Marshall, K., R. White, R., And A. Fischer. 2007. Conflicts between humans over wildlife management: on the diversity of stakeholder attitudes and implications for conflict management. Biodiversity and Conservation 16:3129-3146.

Meryens, A., and C. Promberger. 2000. Economic aspects of large carnivore-livestock conflicts in Romania. Ursus 12:173-180.

Mysterud, A. 2004. Temporal variation in the number of car-killed red deer Cervus elaphus in Norway. Wildlife Biology 10:203-211.

Nowak, S., R. W. Myslajek, A. Klosinska, and G. Gabrys. 2011. Diet and prey selection of wolves (Canis lupus) recolonizing western and central Poland. Mammalian Biology 76:709-715.

Odden, J., J. D. C. Linnell, P. F. Moa, I. Herfindal, T. Kvam, and R. Andersen. 2002. Lynx depredation on domestic sheep in Norway. Journal of Wildlife Management 66:98-105.

Odden, J., Linnell, J. D. C., And R. Andersen. 2006. Diet of Eurasian lynx, Lynx lynx, in the boreal forest of southeastern Norway: the relative importance of livestock and hares at low roe deer densities. European Journal of Wildlife Research 52:237-244.

Olea, P. P., I. S. Sánchez-Barbudo, J. Viñuela, I. Barja, P. Mateo-Tomás, A. Pineiro, R. Mateo, and F. J. Purroy. 2009. Lack of scientific evidence and precautionary principle in massive release of rodenticides threatens biodiversity: old lessons need new reflections. Environmental Conservation 36:1-4. 
Ordiz, A., O. G. Stoen, S. Saebo, J. Kindberg, M. Delibes, and J. E. Swenson. 2012. Do bears know they are being hunted? Biological Conservation 152:21-28.

PAPE, R., AND J. Löfrler. 2012. Climate change, land use conflicts, predation and ecological degradation as challenges for reindeer husbandry in Northern Europe: What do we really know after half a century of research? Ambio 41:421-434.

Pearce, W. B., and S. W. Littlejohn. 1997. Moral conflict: when social worlds collide. Sage, Thousand Oaks, California.

Perea, R., M. Girardello, and A. San Miguel. 2014. Big game or big loss? High deer densities are threatening woody plant diversity and vegetation dynamics. Biodiversity and Conservation 23:1303-1318.

Peterson, M. N., T. R. Peterson, M. J. Peterson, R. R. Lopez, and N. J. Silvy. 2002. Cultural conflict and the endangered Florida Key deer. Journal of Wildlife Management 66:947-968.

Peterson, M. N., J. L. Birckhead, K. Leong, M. J. Peterson, and T. R. Peterson. 2010. Rearticulating the myth of human-wildlife conflicts. Conservation Letters 3:74-82.

Pohja-Mykrä, M., And S. Kurkı. 2014. Strong community support for illegal killing challenges wolf management. European Journal of Wildlife Research 60:759-770.

Pruitt, D. G., AND S. H. Kım. 2004. Social conflict: escalation, stalemate, and settlement. 3erd Edition. McGraw-Hill. New York, USA.

Putman, R.J., P. Duncan, And R. Scott. 2005. Demographic changes in a Scottish red deer population (Cervus elaphus L.) in response to sustained and heavy culling: an analysis of trends in deer populations of Creag Meagaidh National Nature Reserve 1986-2001. Forest Ecology and Management 206:263281.

Redpath, S. M., J. Young, A. Evely, W. M. Adams, W. J. Sutherland, A. Whitehouse, A. Amar, R. A. Lambert, J. D. C. LinnelL, A. Watt, AND E. J. GutiérRez. 2013. Understanding and managing conservation conflicts. Trends in Ecology and Evolution 28:100-109.

RigG, R., S. Findo, M. Wechselberger, M. L. Gorman, C. Sillero-Zubiri, and D. W. Macdonald. 2011. Mitigating carnivore-livestock conflict in Europe: lessons from Slovakia. Oryx 45:272-280.

Ríos-Saldaña, C. A., M. Delibes-Mateos, F. Castro, E. Martínez, J. M. Vargas, B. D. Cooke, and R. Villafuerte. 2013. Control of the European rabbit in central Spain. European Journal of Wildlife Research 59:573-580.

SaArikoski, H., and K. Raitio. 2013. Science and politics in old-growth forest conflict in Upper Lapland. Nature and Culture 8:53-73.

Silva, J. P., J. Toland, T. Hudson, W. Jones, J. Eldridge, E. Thorpe, S. Bacchereti, S. Nottingham, C. Thévignot, ANd A. Demeter. 2013. LIFE and human coexistence with large carnivores. Publication office of the European Union, Luxembourg.

Simón, M. A., J. M. Gil-Sánchez, G. Ruiz, G. Garrote, G., E. B. McCain, L. Fernández, M. López-Parra, E. Rojas, R. Arenas-Rojas, T. del Rey, M. García-Tardío, and G. López. 2012. Reverse of the decline of the endangered Iberian lynx. Conservation Biology 26:731-736.

Smart, J. C. R., P. C. L. White, And M. Termansen. 2008. Modelling conflicting objectives in the management of a mobile resource: Red deer in the Scottish Highlands. Ecological Economics 64:881-892.

Steiner, W., F. Leisch, AND K. Hackländer. 2014. A review on the temporal pattern of deer-vehicle accidents: Impact of seasonal, diurnal and lunar effects in cervids. Accident Analysis and Prevention 66:168181.

Swenson, J. E., F. Sandegren, A. Söderberg, M. Heim, O. J. Sorensen, A. Buärvall, R. Franzén, S. Wikan, and P. Wabakken. 1999. Interactions between brown bears and humans in Scandinavia. Biosphere Conservation 2:1-9.

Thirgood, S., R. Woodroffe, and A. Rabinowitz. 2005. The impact of human-wildlife conflict on human lives and Livelihoods. Pp. 13-26 in People and Wildlife. Conflict or Coexistence? (R. Woodroffe, S. 
Thirgood, and A. Rabinowitz, eds.). Cambridge University Press. Cambrige, United Kingdom.

Thompson, H. V., AND C. M. King. 1994. The European rabbit: the history of a successful colonizer. Oxford University Press. Oxford, USA.

Vaclavikova, M., T. Vaclavik, and V. KostKan. 2011. Otters vs. fishermen: Stakeholders' perceptions of otter predation and damage compensation in the Czech Republic. Journal for Nature Conservation 19:95102.

van Liere, D., C. Dwyer, D. Jordan, A. Premik-Banic, A. Valencic, D. Kompan, and N. Siard. 2013. Farm characteristics in Slovene wolf habitat related attacks on sheep. Applied Animal Behaviour Science 144:46-56.

Wedlock, D. N., M. A. Skinner, G. W. de Lisle, And B. M. Buddle. 2002. Control of Mycobacterium bovis infections and the risk to human populations. Microbes and Infection 4:471-480.

Young. J., A. Watt, P. Nowicki, D. Alard, J. Clitherow, K. Henle, R. Johnson, E. Laczko, D. McCracken, S. Matouch, J. Niemela, AND C. Richards. 2005. Towards sustainable land use: identifying and managing the conflicts between human activities and biodiversity conservation in Europe. Biodiversity Conservation 14:1641-1661.

Young, J., C. Richards, A. Fischer, L. Halada, T. Kull, A. Kuzniar, U. Tartes, Y. Uzunov, and A. Watt. 2007. Conflicts between biodiversity conservation and human activities in the central and eastern European countries. Ambio 36:545-550.

Young, J. C., M. Marzano, R. M. White, D. I. McCracken, S. M. Redpath, D. N. Carss, C. P. Quine, and A. D. WATT. 2010. The emergence of biodiversity conflicts from biodiversity impacts: characteristics and management strategies. Biodiversity and Conservation 19:3973-3990.

Summited: October 8, 2014

Review: November 10, 2014

Accepted: November 13, 2014

Associated editor: William Lidicker 
138 THERYA Vol.6(1): 123-137 